\title{
Intermédialités
}

Histoire et théorie des arts, des lettres et des techniques

Intermediality

History and Theory of the Arts, Literature and Technologies

\section{Telling versus Counting? A Media-Archaelogical Point of View}

\section{Wolfgang Ernst}

Numéro 2, automne 2003

Raconter

Telling

URI : https://id.erudit.org/iderudit/1005455ar

DOI : https://doi.org/10.7202/1005455ar

Aller au sommaire du numéro

Éditeur(s)

Centre de recherche sur l'intermédialité

ISSN

1705-8546 (imprimé)

1920-3136 (numérique)

Découvrir la revue

Citer cet article

Ernst, W. (2003). Telling versus Counting? A Media-Archaelogical Point of View. Intermédialités / Intermediality, (2), 31-44. https://doi.org/10.7202/1005455ar
Résumé de l'article

Il existe une tension épistémologique entre raconter et compter, et cette tension pourrait être perçue comme reposant sur des conditions médiatiques. La thèse que défend cet article est une dé-mystification de l'ère digitale, une sorte d'amnésie média-archéologique : le numérique, qui fonde toute les technologies digitales, a toujours été mis de l'avant comme une pratique culturelle de médiatisation de la réalité. Alors que l'acte de conter a été efficace sur le plan discursif, une autre façon d'aborder et de traiter la réalité a toujours déjà été mise en oeuvre avant d'être techniquement matérialisée. Raconter, après tout, ne veut pas seulement dire « rendre compte oralement ou par écrit d'une série d'événements ou de faits ", mais renvoie également au fait de " compter ". Plutôt que de tenter une trajectoire chronologique linéaire, la relation historique qui lie « raconter » et « compter » pourrait être décrite à partir de reconfigurations dépendant de différents médias. 


\title{
Telling versus Counting? A Media-Archaelogical Point of View
}

\author{
WOLFGANG ERNST
}

B etween the cultural practices of telling and counting one finds both an affinity and a disjunction; narration and the numerical code can be seen as functions of alternating conditions of the media. The numerical order, the basis of digital technologies, has always already been performed as a cultural practice before becoming technically materialized. Rather than attempting a linear chronological trajectory, the changing historical relation between telling and counting can be described as reconfigurations affected by different media or even media theories.

It was a decisive act of cultural engineering in the occident when an unknown adaptor of the Phoenician syllabic alphabet, somewhere in Greece around 800 B.C., invented additional, elementary symbols to register spoken vowels in order to store and transmit Homer's epics. ${ }^{1}$ This brings us close to a media theory of ac/counting: oral traditions privilege the narrative mode; on the level of letters, though, every linguistic unit becomes countable. The form of the Homeric hexameter already provided a mnemotechnical tool, a skeleton that performance could fill with narrative flesh. ${ }^{2}$

Today, in the online-edition of the Microsoft encyclopedia Encarta, we can even hear a spoken rendition for the very literal entry tell, a re-entry of orality that is filtered by digital procedures. ${ }^{3}$ To tell, we learn, as a transitive verb does

1. See Barry B. Powell, Homer and the Origin of the Greek Alphabet, Cambridge, Cambridge University Press, 1991.

2. See Joachim Latacz, Troia und Homer, Munich, Berlin, Verlag Koehler \& Amelang, 2001.

3. Encarta ${ }^{\circledR}$ World English Dictionary [North American Edition] (C) \& (P) Microsoft Corporation, 2001, http://dictionary.msn.com/find/entry.asp?refid=1861718905. 
not mean only "a live account in speech or writing of events or facts" (that is, to tell a story), but also "to count things" (to tell a rosary, for example). The very nature of digital operations and telling thus coincide.

\section{ANNALS}

The old English tellan derives from a prehistoric Germanic word meaning "to put in order" (both in narration and counting). We find this kind of non-explanatory and paratactic mode in the epic discourse. ${ }^{4}$ Homer, in his Iliad, already used the form of listing in the appropriately called "Catalogue of Ships" - literally counting the ships and their leaders by names (see especially verse B 493). This set-piece description is paradigmatic of a narrative pause, "a passage at the level of narration to which nothing corresponds at the level of story. The plot does not advance, but something is described." ${ }^{5}$ How can such a form of listed knowledge be culturally transmitted over centuries? The bard may actually have inherited the form of memory kept by military lists of troops in the Mycenaean age, written in linear $B$, that is, a muster-list which he turned into verse? ${ }^{6}$ Here, telling is counting ${ }^{7}$ - a practice well known from ancient Oriental lists of rulers.

Narration assimilates information by re-counting it in the synecdochical mode. ${ }^{8}$ To narrate, we learn from Webster's Revised Unabridged Dictionary (1913), is etymologically related to knowing. Knowledge in fact is coupled to the very act of telling, i.e. providing a narrative sequence when apparently insignificant facts are being interwoven into a complex reality that cannot be observed directly. Between counting and telling, such sequences are well known from nonliterary accounts of history. Gregory of Tours, in the early medieval age, wrote

4. See William J. Brandt, The Shape of Medieval History, New Haven, Yale University Press, 1966, p. 86.

5. Don P. Fowler, "Narrate and Describe: The Problem of Ekphrasis", in The Journal of Roman Studies, No. 81, 1991, p. 25.

6. Or is it indeed "much more likely that the Catalogue began as it ended, as poetry”? Richard Hope Simpson, John F. Lazenby, The Catalogue of the Ships in Homer's "Iliad", Oxford, Clarendon Press, 1970, p. 160.

7. Christoph Albrecht, "Listen von Macht und Begehren", Frankfurter Allgemeine Zeitung, No. 144, June 25, 2002, p. 49.

8. See Hayden White, Metahistory: Historical Imagination in Nineteenth-Century Europe, Baltimore, Johns Hopkins University Press, 1973. 
a history of mankind year by year (cunctam annorum congeriem connotare), with the connotation of connotare being both "telling" and mathematical counting in discrete leaps. Today, historiography rigorously separates narrated time from calculated time, but early Medieval Europe reads them together. ${ }^{9}$ For example, in Regensburg, a supplement to the Annales Fuldenses comments on the year 884: instanti anno, quo ista conputamus. ${ }^{10}$ The conjunction between telling stories and counting time is more than just a word game: verbs like conter, contar, raccontare, erzählen, to tell are testimonies of a way of perceiving realities that oscillate between narrative and statistics.

erzählen, ahd. irzellen (8. Jh.), mhd. erzel(le)n steht zunächst (ähnlich wie ahd. zellen, mhd. zeln, s. zählen) für zählen, (der Reihe nach) aufzählen, auch bei der Darstellung von Ereignissen und Taten, daher (im Rechtswesen) „öffentlich hersagen und verkünden“ und allgemein „mündlich mitteilen, berichten“. Die letztere Bedeutung ist dann allein auf erzählen übergegangen, während nhd. zählen auf den rechnerischen Bereich eingeschränkt wird; doch hält sich die alte Bedeutung „aufzählen“ gelegentlich bis ins 18. Jh. ${ }^{11}$

In later medieval times, telling-as-counting was not restricted to linguistic practices. The hourly ringing of bells in monasteries - an acoustic media of structuring time - as well reminded of a technologically enhanced rule-governed, almost algorithmic symbolic order. The meaning of Latin computus thus encompassed a mechanical order as well as a symbolical one, and the quantification of time was transformed from an ancient counting to an allegorical interpretation.

To tell as a transitive verb means "to count things". When all sensual dimensions are quantifiable, even the temporal resolution, telling gets liberated

9. Arno Borst, Computus. Zeit und Zahl in der Geschichte Europas, Berlin, Verlag Klaus Wagenbach, 1990, p. 29-116; footnote p. 77.

10. "In this very year when we are telling this story...", quoted in Arno Borst, Computus. Zeit und Zahl in der Geschichte Europas, p. 41, referring to Annales Fuldenses (anonymous medieval author), anno 884, in Monumenta Germaniae Historica, series Scriptores rerum Germanicarum, vol. 7, Hannover, 1891, p. 112.

11. 'In medieval German, 'erzählen' (telling) originally meant counting in a sequential order. For example, in the representation of events, which in legal matters got the meaning of 'public declaration' as well. This meaning shifted to what we mean by telling today, while 'zählen' got restricted to counting, even if both uses could overlap until the 18th century." Etymologisches Wörterbuch des Deutschen, Wolfgang Pfeifer (ed.), Berlin (Akademie), 1993, p. 298. My translation. 
from the narrative grip - a media-archaeological amnesia of cultural techniques like that of the early Medieval annales, a sequential notation of temporal events with no metahistorical, narrative prefiguration. We get a glimpse of a way of processing cultural experience that does not need stories (not yet? not any more?). Modern historians, though, are obliged not just to order data like antiquaries, but also to propose models of relations between them, to interpret plausible connections between events. Here, the difference between tableau as statistical form (annalism) and as painting (historiography) becomes evident. According to George Kubler it is the historian's task to recognize the shape of time and to describe it appropriately on different kinds of tableaux. ${ }^{12}$ The Annales Sangallenses, figuring as an early medieval form of record of events in the 1826 scholarly edition of the Monumenta Germaniae Historica (series Scriptores), render events (like the medieval recordatio) as a list of entries, but also of non-entries, empty storage spaces that provide gaps for reading, silence as statement. Chronometrics count with non-events as well - the serial character of human existence (fig. 1).

As we learn from Lessing's 1766 treatise Laocoön, only such gaps make readers or betrayers participate actively, since they project their own visions (letters, images) into the voids - the condition for aesthetic experience. ${ }^{13}$ It was with the invention of printing that Gutenberg could, in a media-archaeological context, literally calculate with empty spaces: in printing (as with typewriters and computer keyboards), even the empty key counts. In digital o/1 computing, even absence counts as value - nulla rosa est (as expressed in medieval scholastics). "Chante (imagine), ma Muse, le Rien: ne méprise pas la tâche / Car Rien est une gemme, Rien est de l'or précieux."14 Does something like "human nature" really ask to avoid semantic vacui ? $^{15}$ Even annalism with all its discrete

12. George Kubler, The Shape of Time: Remarks on the History of Things, New Haven, London, Yale University Press, 1963.

13. Hans Dieter Huber, Angela Bulloch, Die Matrix des Sehens, Handout (May 2002) to the exhibition of Angela Bulloch's Pixel Works in the art gallery Schipper \& Krome, Berlin, June-July 2002.

14. Jean Passerat, Carmen De Nihilo, in Marten Schoock, Tractatus Philosophicus de nihilo, Groningen, Typis Viduae Edzardi Agricole, 1661, p. 125. See Victor I. Stoichita, L'instauration du tableau. Métapeinture à l'aube des Temps Modernes, Paris, Méridiens Klincksieck, 1993, p. 300.

15. Matthew Schlesinger, "Production of Utterance and Language Acquisition", in Dan Isaac Slobin (ed.), The Ontogenesis of Grammar, New York, Academic Press, 1971, p. 63-101. 


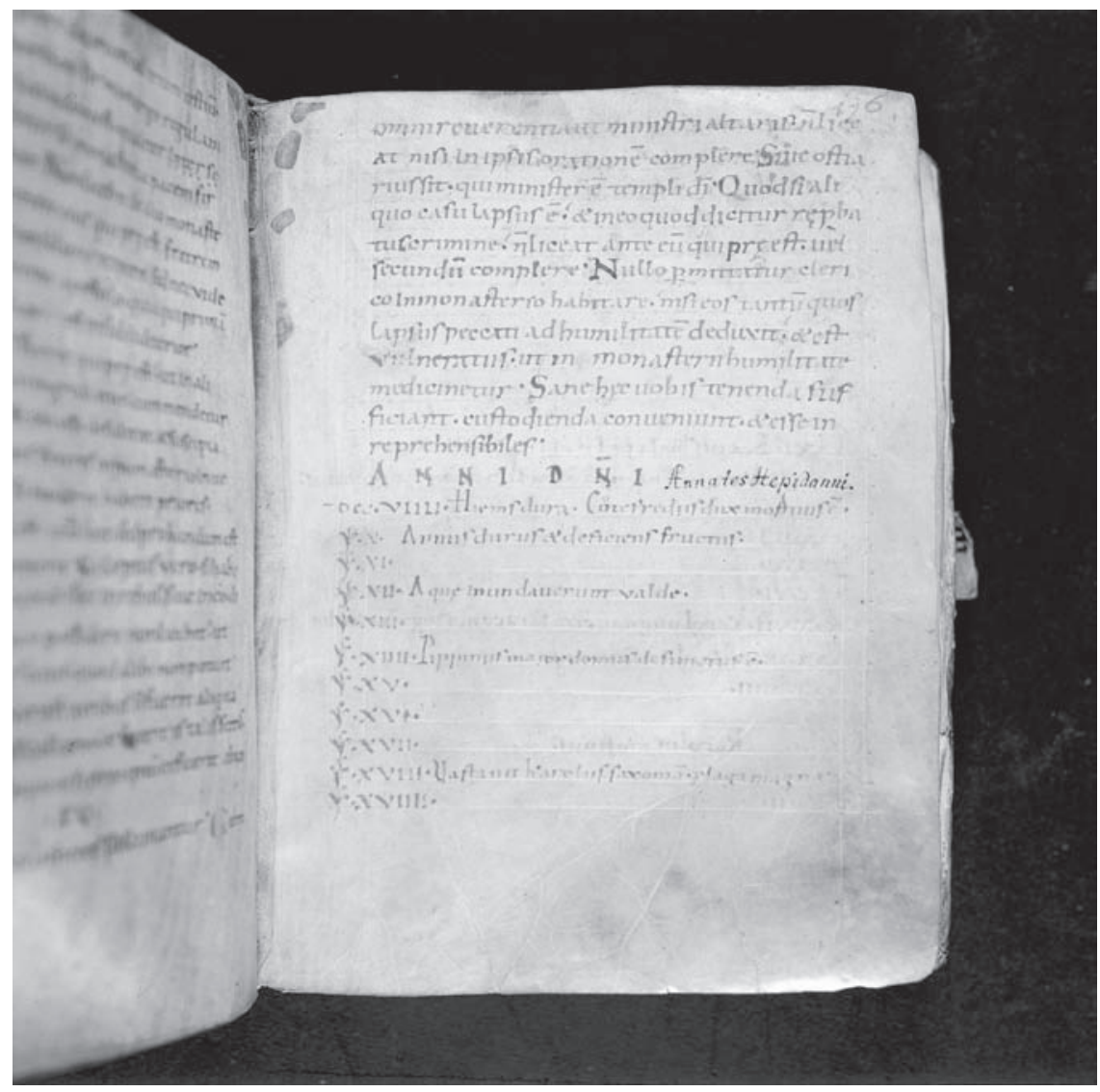

Fig. 1. Anonymous, Annales Sangallenses Maiores, Codex 915, MS, p. 196, year 956 (with kind permission by Stiftsbibliothek St. Gallen, Switzerland).

gaps implicitly imposes a narrative form on the events by means that are poetic in nature: ${ }^{16}$

The Middle Ages stood by the archaeologist. His ability to look at mere fragments in a glass case and yet see the whole vessel as it should appear and to forget completely its fragmentary state, this ability was native to the medieval mind. [...] The medieval mind set the Whole before the parts and found it easier than we do

16. Hayden White, The Content of the Form: Narrative Discourse and Historical Representation, Baltimore, London, Johns Hopkins University Press, 1987, p. 42. 
to acknowledge a totality, even an imaginary one. The absence of unity was considered a momentary defection, which could be overlooked because sooner or later the unity would have to be restored. ${ }^{17}$

Historical imagination asks for iconic coherence, to be separated from the organization of knowledge about the past in the form of naked data banks. But registering time does not necessarily require the narrative mode to organize the factual field in a form that we call information. In digital computing, the sequence of operations required to perform a specific task is known as an algorithm. ${ }^{18}$ Medieval annalism as well stands for a writing aesthetics of organizing a sequence of events in serial, sequential order, and Pierre Chaunu invented the notion of histoire sérielle for the non-narrative histories of the Parisian École des Annales. ${ }^{19}$ Here, diachronical clustering serves as a memory operation beyond the narrative unification of data. Just like in early annalism,

[...] quantitative history's most general and elementary object is to form historical fact into temporal series of homogeneous and comparable units, so that their evolution can be measured in terms of fixed intervals, usually years. ${ }^{20}$

There can be order without stories, since documents and data here exist not for themselves but in relation to the series that in each case precedes or follows - without being subjected to romance, where causality and the foregrounding and backgrounding of events are expressed through explicit narrative subordination. Is the narrative vantage point, the point-of-view (the "SehePunkt"21) or focus, a cultural side effect of the painterly mathematical perspective invented in the Renaissance (Brunelleschi, Alberti)? Machiavelli, for example, originally got the order to write annalia et cronacas. Instead, he provided his composition with divisioni, that is, leaps back and forward within an all-encompassing historical perspective. This might indeed be compared with

17. Ernst H. Kantorowicz, "The Problem of Medieval World Unity”, The Annual Report of the American Historical Association for 1942, Vol. III, Washington, 1944, p. 33.

18. Julian Richards, Nick Ryan (eds.), Data Processing in Archaeology, Cambridge, Cambridge University Press, 1985, p. 1.

19. See Pierre Chaunu, Histoire quantitative, histoire sérielle, Paris, Armand Colin, 1978.

20. François Furet, "Quantitative History”, in Felix Gilbert, Stephen R. Graubard (eds.), Historical Studies Today, New York, Norton, 1972, p. 47.

21. Johann Martin Chladenius, Einleitung zur richtigen Auslegung vernünftiger Reden und Schriften, Leipzig, reprint: Düsseldorf, Stern-Verlag, 1969 [1742], p. 185-189. 
the discovery of central perspective in the optical arts. ${ }^{22}$ In early 19th century, the historian Barthold Niebuhr reflects upon annalism as a semiotic index of temporal processes: a marking of events year by year, without historical horizon. Then Niebuhr contrasts annalism with historiography, "a comprehensive narration whose object has been accomplished and fulfilled [...] stories describe and explain." ${ }^{23}$ His use of the verb schildern (pictorial description) already indicates an intermedial change from alphanumerical listing to the iconic realm. In his fragment "Apokatastasis panton", the philosopher Gottfried Wilhelm Leibniz actually mused on the option to calculate a virtual protocol of the world by counting, not narrating: combining and re-combining every letter that has ever been written in world history. Once registered in discrete symbols, events can be literally processed. "Thus I found everything which needs to be told." 24 This form can match every object, every referent.

Is there really something like an anthropological need to link unconnected, contingent experience into narrative wholes? The author of an autobiography recalls that once he had discovered in the New York Times Index what else had been happening at the time of some personal event, he could scarcely resist connecting the lot into one coherent whole- "connecting, not subsuming, not creating historical-causal entailments, but winding it into the story." 25 Historical discourse tends to deflect attention from data to structures of consciousness. The narrative construction of reality is a cultural sense-making pattern; thus common universal history is a hybrid made from legends and annalistic handbooks. ${ }^{26}$ The discrete counting of data "factualism", according to Gérard

22. Gisela Bock, "Machiavelli als Geschichtsschreiber", in Quellen und Forschungen aus italienischen Archiven und Bibliotheken, vol. 66, Tübingen, Niemeyer, 1986, p. 175.

23. Barthold G. Niebuhr, "Ueber den Unterschied zwischen Annalen und Historie", in Kleine historische und philologische Schriften, Bonn, 1828 [1827], second volume, reprint: Osnabrück, 1969, p. 229-241, quote p. 229.

24. See Max Ettlinger, Leibniz als Geschichtsphilosoph, Munich 1921, with an edition of Leibniz' fragment "Apokatastasis panton" [1715], p. 27-34. See also Hans Blumenberg, Die Lesbarkeit der Welt, 3rd ed., Frankfurt am Main, Suhrkamp, 1993 [1983], p 121-149, quote p. 128.

25. Jerome Bruner, "The Narrative Construction of Reality”, Critical Inquiry, No. 18, Autumn 1991, p. 19.

26. Siegfried Kracauer, Geschichte. Vor den letzten Dingen, trans. Karsten Witte, Frankfurt am Main, Suhrkamp, 1971 [1969], p. 177. 
Genette, ${ }^{27}$ instead of its narration, resembles a diagram rather than a picture and requires anonymous pattern recognition instead of the personal narrator. Between the discrete entries, though, there is always space left for biographical micro-narrative information.

Chronology may supply order in the temporal arrangement of events, but it does not supply explicit patterning, and that is what separates proper history from chronicles and annals. The explicit plotting of time describes, organizes, and explains events, persons, and actions in the past all at one and the same time. Chronicles offer their readers "one thing after the other"; proper histories provide their readers with "one thing because of the other". ${ }^{28}$

When Lessing published his essay Laokoon oder die Grenzen der Malerey und der Poesie, he revolutionized meditations on the semiotics of the arts by providing them with a media theory (as opposed, for example, to Immanuel Kant's rather abstract notion of a spatio-temporal a priori). Lessing discusses the different aesthetic qualities of one and the same subject (the death of Trojan priest Laocoön and his sons) in sculptural versus epic representation (Homer's Iliad, Virgil's Aeneid). Thus Lessing has become a theoretician of "intermediality" avant la lettre, by insisting that-based on their respective media qualitiespainting cannot simply be translated into poetry and vice versa. According to Lessing, "succession of time is the province of the poet just as space is that of the painter." ${ }^{29}$ His argument of space-based versus time-based arts seems more actual than ever (at least as a media-analytic question). Whereas in art historical iconology literature and the visual arts seem to be interchangeable in ekphrasis, the archaeological gaze registers their discontinuity; classical archaeologists refuse to compare the Homeric epic with the figures on the Dipylon vase. Homer's description of Achilles's shield seems to fulfil Lessing's aesthetic claim, since instead of a verbal picture he gives us the genetic story of how the weapon is

27. See Gérard Genette, Narrative Discourse, trans. Jane E. Lewin, Oxford, Basil Blackwell, 1980.

28. Robert F. Berkhofer (Jr.), Beyond the Great Story: History as Text and Discourse, Cambridge (MA.), Belknap Press of Harvard University Press, 1995, p. 117.

29. Gotthold Ephraim Lessing, Laocoön: An Essay on the Limits of Painting and Poetry, trans. Edward Allen McCormick, Baltimore, John Hopkins University Press, 1984 [1766], p. 91. 
being made by the god Hephaistos. In this literary description of a work of art, we find traces of both linearization and non-linearization. We find a similar situation in book I of Virgil's Aeneid: when the protagonist is thrown on the shore of Carthage, he is surprised to see scenes of warfare he is familiar with in the painted panels that decorate the temple of Juno. In fact, he sees his own past as part of the Trojan War. In the logic of Virgil's epic this leads to an ekphrasis with Aeneas telling the stories of what he sees:

In this $[\ldots]$ Virgil has confused the pictorial and the narrative, and in so doing he has subordinated the art of Dido's Punic painters to the art of the Aeneid. In Virgil's ekphrasis, we begin with spatial markers [...]. These are qualified and finally replaced by the strictly temporal habits of the narrative $[\ldots]$; significantly, Aeneas is pulled into the temporal, not painterly, narrative by this sympathetic response $[\ldots]$. [...] The Virgilian narrative gains ascendancy over the pictorial. ${ }^{30}$

Description is at odds with narrative, as accentuated in the appropriate entry in the Encyclopédie ou Dictionnaire raisonné des sciences, des arts et des métiers (1751-1780). In natural history it means a discrete mode of representation ("Plus un corps est composé, plus il est nécessaire de décrire les détails de son organisation, pour en exposer le jeu \& la mécanique"; in geometry it means "l'action de tracer une ligne, une surface, etc."); finally in literature:

Une description est l'énumération des attributs d'une chose, dont plusieurs sont accidentelles [...]. Une description au premier coup d'œil a l'air d'une définition; elle est même convertible avec la chose décrite, mais elle ne la fait pas connoître à fond, parce qu'elle n'en renferme pas ou n'en expose pas les attributs essentiels. ${ }^{31}$

That is, description remains exterior to the essence of things - by virtue of the archaeological (instead of the historicizing) gaze.

\section{SPACE, MOVEMENT, CINEMATOGRAPHICS}

Is film the media-dialectical conjunction of the two semiotic regimes Lessing tried to separate categorically? Cinematography has created a new perception of central temporal categories like simultaneity and the spatialization of time;

30. Diskin Clay, "The Archaeology of the Temple to Juno in Carthage (Aen. 1.44693)", Classical Philology, No. 83, January 1988, p. 200.

31. Encyclopédie ou Dictionnaire raisonné des sciences, des arts et des métiers, vol. 4, Paris, 1754 , p. 878 . 
"thus film has merged Lessing's separation of spatially and temporally performative arts." ${ }^{2}$ In his theory of cinematographic montage, Sergei Eisenstein refers to El Greco's painterly representation of Laocoön in order to describe his idea of the "ecstatic" moments in film. ${ }^{33}$ And any attempt to put the Laocoön sculpture into film would have to refer to Virgil's narrative in order to get to a dramatic climax of the figurative constellation and picturesque pose of the Trojan priest and his sons at the moment of deadly out-cry (as action). ${ }^{34}$ Lessing's differential media theory of spatiality (painting, sculpture) versus temporality (verbal narrative) has indeed been translated into film theory by Rudolf Arnheim. His essay "New Laocoön" tries to defend the art of silent movies against the new age of film + sound, that is, from the moment when text, in the form of voices and voice-over, enters not only the space between the images but the images themselves. Only with silent movies did Arnheim see the chance for the appropriate representation of "pregnant moments" (as Lessing called them) that require implicit rather than verbally explicit expression. ${ }^{35}$ How close is film to theatre (Lessing's telos)? Jean-Luc Godard's movie Passion (1982) freezes the temporal succession of moving images into painterly stillness of pregnancy (gestures of passion, in Aby Warburg's sense) by letting his actors perform tableaux vivants of famous pictures like Rembrandt's Die Nachtwache (1642). A "still" composed from moving images is uncanny, however, resulting in a cognitive dissonance. Dynamic stasis is a paradox, a non-narrative.

32. Walter Hagenbüchle, Narrative Strukturen in Literatur und Film. Schilten ein Roman von Hermann Burger. Schilten ein Film von Beat Kuert, Bern et al., Lang, 1990, p. 93.

33. See Manfredo Tafuri, "The Dialectics of the Avantgarde: Piranesi and Eisenstein”, Oppositions. A Journal for Ideas and Criticism in Architecture, No. 11, Winter 1977, p. $72-$ 110. Also Sergei Eisenstein, "Piranesi, or the Fluidity of Forms", Manfredo Tafuri (ed.), The Sphere and the Labyrinth, Avant-Gardes and Architecture from Piranesi to the 1970s, Cambridge, Massachusetts, MIT Press, 1990.

34. Joachim Paech, Passion oder die Einbildungen des Jean-Luc Godard, Frankfurt am Main, Deutsches Filmmuseum, 1989, p. 41. See also, by the same author, "Eine Szene machen. Zur räumlichen Konstruktion filmischen Erzählens”, in Hans Beller u.a. (ed.), Onscreen / Offscreen. Grenzen, Übergänge und Wandel des filmischen Raumes, Stuttgart, Verlag Hatje Cantz, 2000, p. 93-121.

35. Rudolf Arnheim, "A New Laocoön. Artistic Composites and the Talking Film", Film as Art, Berkeley, Los Angeles, London, University of California Press, 1957, p. 199230. 
Media-archaeology of cinematography frequently refers back to the kind of chronicle of events depicted on the so-called Tapestry of Bayeux, where the continuous story of the Norman invasion of England is rythmically interrupted by the painterly interpolation of trees and towers that both link and separate the single "frames." This is a pre-cinematic form of cutting that has often been compared to film or comic strips, with abrupt changes of place, jumps in time and flash-backs (while the tapestry, in fact, guides the eye successively through time and space). ${ }^{36}$ Film, in the sense of Lessing's Hamburger Dramaturgie and Hugo Münsterberg's Photo-Play, remembered for its close connections with theatre, cannot show the simultaneous coexistence of action in space; a dialogue, for example, is represented by a sequence of shot and counter-shot, thus cutting homogeneous space into segments. At this point, a virtual space is created on a cognitive level in the viewer's mind. Physically, though, film puts sequences one after another on the celluloid reel-just like on the Bayeux tapestry.

Similarly, the tri-partite video-projection You never know the whole story by Ute Friedrike Jürß in the Museum for Contemporary Art (ZKM Karlsruhe, 2000) presented electronic images in narrative recess; the apparent lack of motion resulted from the different media pattern: "In spite of Lessing's Laocoön claim, the press-photography-different from sculpture and painting - by its very nature as a momentary snap-shot, is already, by its very mode of production, an image of time brought to a stand-still." ${ }^{37}$ The theatrical or filmic tableau vivant differs from a classical painting exactly by being time-based. Thomas Levin calls this media crossover, this paradoxical translation of Lessing's paradigm into the age of electronic media, "hybrid intermediality". ${ }^{38}$ Does installation art return us to the spatial dimension of the image?

36. Ulrich Kuder, Der Teppich von Bayeux oder: Wer hatte die Fäden in der Hand?, Frankfurt am Main, Fischer, 1994, p. 7-26 (23); see also Anatole Jakovsky, "Encore quelques mots en marge de la Tapisserie de Bayeux”, L'Âge Nouveau, vol. 21, 1947, p. 24-27, which compares the tapestry with early Russian films.

37. Thomas Y. Levin, "You Never Know the Whole Story. Ute Friederike Jürß und die Ästhetik des heterochronen Bildes", in Ute Friederike Jür $\beta$, "You Never Know the Whole Story" (exhibition catalogue), Götz Adriani (ed.), Ostfildern-Ruit, Verlag Hatje Cantz, 2000, p. 57.

38. Thomas Y. Levin, "You Never Know the Whole Story", p. 61. 
What better place than the museum to confront the cinema once more with itself and its history? A curious set of parallels has evolved between the museum as a space of contemplation, and the electronic vision machines [...]; the museum as a site of aesthetic distance and reflection, and scientific instruments of calculation, of mathematics as means of measuring and monitoring. ${ }^{39}$

The very technical apriori (more or less 24 frames per second) of any film or video projection of a tableau vivant undercuts the apparent visual simultaneity. The indexical basis of technical images is no longer space but time (and its time-axis manipulation) - which links it with narrative in a way that Lessing wanted to exclude. But there are forms of re-entry for space, a kind of second order return to Lessing's theorem. Montage, as the internal operation of moving images in Mike Figgis' movie Timecode (2000), takes place not only in time but in space as well, on the squared screen, thus surpassing Robert Altman's Short Cuts (1993). In a dialogue at the end of the film this form becomes ironically self-reflexive in a kind of parody of early Soviet theories of cinematographic montage: "Beyond montage. Digital video has arrived at last."

the spatialization of telling: digital aesthetics (INTERNet ANd COMputer games)

Against cinematographic sequencing, digital interface aesthetics privileges spatialization again, with its Windows perspective and hypertextual logic. Pixelbased media lead to the re-entry of narrative as calculation, and in the acoustic realm (techno-music) allows for sampling and intervals by time-stretching and time-compression. ${ }^{40}$ Narrative on the emphatic literary level (raconter) is being replaced by literally counting micro-events on the media-archaeological level.

Among the attempts to spatialize digital communication, the Virtual Reality Modeling Language was conceived for virtual worlds hyperlinked with the World Wide Web. And computer games, though apparently performing stories or at least plots on the surface level, are not based on linear narratives any more, but strictly on algorithms and processual trees. Maybe in a deep culturaltechnological perspective, this is no contradiction:

39. Thomas Elsaesser, "Introduction: Harun Farocki", Senses of Cinema, No. 21, 2002, http://www.sensesofcinema.com/contents/o2/21/farocki_intro.html.

40. Honke Rambow, "Rhythmus, Zeit, Stille", in Kunstforum International, No. 151, July-September 2000, p. 179-184. 
In many computer games, from the original Zork to the best-selling CD-ROM Myst, narrative and time itself are equated with movement through space (i.e., going to new rooms or levels). In contrast to modern literature, theater, and cinema, which are built around the psychological tensions between characters, these computer games return us to the ancient forms of narrative where the plot is driven by the spatial movement of the main hero, traveling through distant lands. ${ }^{41}$

The co-ordinates of three-dimensional space become the medium of ac/ counting-beyond writing. Is this the return to an ancient Greek, topologybased notion of narrative diegesis, which effectively meant routing? ${ }^{42}$ Augmented Reality plays with this practice, when the user in real (urban) space is being equipped with a mini-computer, a GPS receiver and audio-visual devices.

In the digital era, with its re-entry of narrative as calculation, the question arises as to whether "intermediality" is not already a perspective of the previous media age, since in digital space all sensual differences between images, sounds and texts are equally dissolved into strings of numbers. Thus it is worth remembering once more a different, non-narrative meaning of telling: "to be able to distinguish things", "to be able to tell one thing from the other" - the very nature of binary calculations. This addresses the core problem of digital mediality, with its smallest units (bits) being arranged in differential sequences. The media artist Angela Bulloch extremely slows down a digitized version of Michelangelo Antonioni's movie Blow-Up (1966) and at the same time extremely enlarges the single pixels, thus making the media-archaeological level of digital narrative transparent by geometrizing the traditional cinematic frame (even more radically than the video by Les LeVeque, 4 Vertigo (2000), which sequentializes Alfred Hitchcock's movie down to the level of one frame per second). Temporally serial data are thus being re-translated into spatial orders again - reminding us of the pre-modern cultural engineering of memory (ars memoriae).

Behind the celebrated pictorial turn we find nothing else but the calculating space from Gotthold Ephraim Lessing's textually expressed theory of timeand space-based arts to Peter Greenaway's experimental movie Drowning by Numbers (1988) and Bulloch's media-archaeology of discrete pixels. Theoría

41. Lev Manovich, "Global Algorithm 1.3: The Aesthetics of Virtual Worlds. Report From Los Angeles”, Ctheory, 22 May 1996, http://www.ctheory.net/text_file.asp?pick=34 42. Michel de Certeau, The Practice of Everyday Life, trans. Steven Rendall, Berkeley, University of California Press, 1984, p. 129; originally published as: L'invention du quotidien. 1. Arts de faire, Paris, Union générale d'éditions, 1980. 
wanders from the visual to the numerical. Digital media, in fact, reduce everything to numbers, with profound consequences for the nature of visual realism. "When all dimensions that affect the reality effect-detail, tone, colour, shape, movement-are quantified," reality itself can be related to a set of numbers $^{43}$ - a world-view well known from Pythagoras, a cultural-technological Moebius-loop between 5th century Greece (B.C.) and the present. Thus Lessing's essay on Laocoön, when revisited with a media-archaeological perspective, is worth reading against its own logic; the opposition between space-based visual media and time-based literary media collapses when telling becomes counting by numbers again. 